\title{
Chromatographic Separation of Heavy Metal Cations on a Silica Gel-G with Amino Acid
}

\author{
S. M. WANJARI* ${ }^{1}$, LATA DESHMUKH ${ }^{1}$, AND L. J. PALIWAL $^{2}$ \\ ${ }^{1}$ Dr. Mrs. Ira N. Nimdeokar P.G. \& Research Centre for Chemistry, \\ Hislop College, Nagpur-440001 (M.S.), India \\ ${ }^{2}$ Post Graduate Department of Chemistry, Mahatma Jyotiba Phule Campus, RTM Nagpur \\ University, Nagpur-440033 (M.S.), India \\ wanjari_sunil@yahoo.com
}

Received 01 October 2011; Accepted 30 December 2011

\begin{abstract}
Thin layer chromatographic method has been developed for the separation of metal ions such as $\mathrm{Cr}(\mathrm{VI}), \mathrm{Cr}(\mathrm{III}), \mathrm{As}(\mathrm{III}), \mathrm{Cd}(\mathrm{II})$, $\mathrm{Tl}(\mathrm{III})$ and $\mathrm{Hg}(\mathrm{II})$ from their two, three and four component mixtures. The separations were performed on thin layer of silica gel ' $G$ ' using aqueous 1-Alanine as mobile phase. The effect of concentration and $\mathrm{pH}$ of mobile phase on the $R_{f}$ values of individual metal ions were studied and the optimum conditions for separation of metal ions from their mixture were determined.
\end{abstract}

Keywords: Thin layer chromatography, Separation, Silica gel-G, 1-Alanine, Toxic Heavy Metal Ions.

\section{Introduction}

Thin layer chromatography (TLC) is considered to be superior to other chromatographic techniques, because of its simplicity and relatively low cost. Success in TLC depends to great extent upon the proper selection of the mobile phase. The separation possibilities in TLC are greatly enhanced when chromatoplates are developed with mixed solvent systems. TLC has been successfully utilized for various purposes, such as the separation of metal ions from a water sample[1], the characterization of the mobility of metal[2], and the estimation of concentration of toxic metal in industrial waste[3]. The use of aqueous solution as a mobile phase in TLC was pioneered by Armstrong and Terrill[4]. Using a surfactant as the mobile phase gained popularity and became more widely applied due to its operational simplicity, cost effectiveness, relative non-toxicity and enhanced separation efficiency [5-8]. The use of silica gel and an alumina layer with surfactant mediated mobile phase systems[915] has been used to separate various inorganic species. Number of metal ions was systematically chromatographed on thin layer of urea formaldehyde polymer[16].

In this paper chromatographic separation was carried out on silica gel-G using aqueous solution of 1-Alanine as mobile phase. 


\section{Experimental}

\section{Chemicals and Reagents}

l-Alanine (E. Merck; India); Silica gel-G (E. Merck; India); Hydrochloric acid and Sodium hydroxide. All chemicals were of analytical reagent grade.

Metal ion Studied: $\mathrm{Cr}(\mathrm{VI})$; $\mathrm{Cr}(\mathrm{III})$; $\mathrm{Cd}(\mathrm{II})$; Tl(III); $\mathrm{As}(\mathrm{III})$, and $\mathrm{Hg}(\mathrm{II})$.

Test Solutions: TLC was performed using a standard aqueous solutions $(0.05 \mathrm{M})$ of potassium dichromate, chromium sulphate, cadmium chloride, thallium oxide and arsenic oxide, and mercuric chloride.

Detection: The metal ions[17] were detected using $0.05 \%$ Dithiozone in Carbon tetra chloride for $\mathrm{Cd}(\mathrm{II})$; $\mathrm{Tl}(\mathrm{III})$; $\mathrm{As}(\mathrm{III})$ and $\mathrm{Hg}(\mathrm{II})$. Saturated alcoholic $\mathrm{AgNO}_{3}$ for $\mathrm{Cr}(\mathrm{VI})$ and saturated alcoholic Alizarin red for Cr(III).

Stationary Phase: Silica gel-G.

Mobile Phase: The aqueous solution of 1-Alanine as the mobile phase.

A. Preparation of Plates: The TLC plates were prepared by mixing silica gel-G with deminerlised water in 1:2 ratio by weight with constant stirring to obtain homogeneous slurry. It was then immediately applied on the glass plates by dipping method[18]. The plates were allowed to dry over night at room temperature and were used next day for TLC.

B. Procedure: Test solutions were spotted onto thin layer plates with the help of a micropipette positioned about $1.0 \mathrm{~cm}$ above the lower edge of the TLC plates. The spots were air dried and the plates were then developed with the given mobile phase using by one dimensional ascending technique in glass jars. The development distance was fixed at $10 \mathrm{~cm}$ in all cases. Following development, the plates were again air dried and the spots of the Cations were visualized as coloring spots using the appropriate spraying reagent. $\mathrm{R}_{\mathrm{f}}$ values were then calculated.

C. Separation: For the separation, the metal ions to be separated were mixed in equal amounts. A test solution of the resultant mixture was spotted onto the activated TLC plate, and was then air dried. The plates were developed to a distance of $10 \mathrm{~cm}$. The spots were detected and the separated metal cations were identified by their $R_{f}$ values.

\section{Results and Discussion}

\section{Effect of Concentration}

This section deals with the separation of $\mathrm{Cr}(\mathrm{VI})$; $\mathrm{Cr}(\mathrm{III})$; $\mathrm{As}(\mathrm{III})$; $\mathrm{Cd}(\mathrm{II})$; $\mathrm{Tl}(\mathrm{III})$ and $\mathrm{Hg}(\mathrm{II})$. Various experiments were carried out at different development time, different $\mathrm{pH}$ and at different concentration of 1-Alanine for determining optimum condition for separation of the metal ions.

The results dealing with the effect of concentration of mobile phase, i.e. on the $R_{f}$ values of different metal ions such as $\mathrm{Cr}(\mathrm{VI})$; $\mathrm{Cr}(\mathrm{III})$; $\mathrm{As}(\mathrm{III})$; $\mathrm{Cd}(\mathrm{II})$; $\mathrm{Tl}(\mathrm{III})$ and $\mathrm{Hg}(\mathrm{II})$ are represented graphically in fig. 1 and tabulated in table 1 . The variations in the $\mathrm{R}_{\mathrm{f}}$ values with concentration in the range of 0.005 to $0.1 \mathrm{M}$ were studied in $\mathrm{pH}$ range of 1 to 7 .

Table 1. Effect of Concentration on the $\mathrm{R}_{\mathrm{f}}$ values of metal ions.

\begin{tabular}{|c|c|c|c|c|c|c|}
\hline $\begin{array}{c}\text { Concentration } \\
(\mathrm{M})\end{array}$ & \multicolumn{7}{|c|}{ Metal Ions } \\
\cline { 2 - 7 } & $\mathrm{Cr}(\mathrm{VI})$ & $\mathrm{Cr}(\mathrm{III})$ & $\mathrm{As}(\mathrm{III})$ & $\mathrm{Cd}(\mathrm{II})$ & $\mathrm{Tl}(\mathrm{III})$ & $\mathrm{Hg}(\mathrm{II})$ \\
\hline 0.005 & 0.91 & 0.23 & 0.80 & 0.37 & 0.44 & 0.89 \\
\hline 0.01 & 0.96 & 0.23 & 0.82 & 0.45 & 0.49 & 0.87 \\
\hline 0.05 & 0.93 & 0.26 & 0.85 & 0.56 & 0.53 & 0.86 \\
\hline 0.1 & 0.94 & 0.48 & 0.79 & 0.65 & 0.59 & 0.87 \\
\hline
\end{tabular}




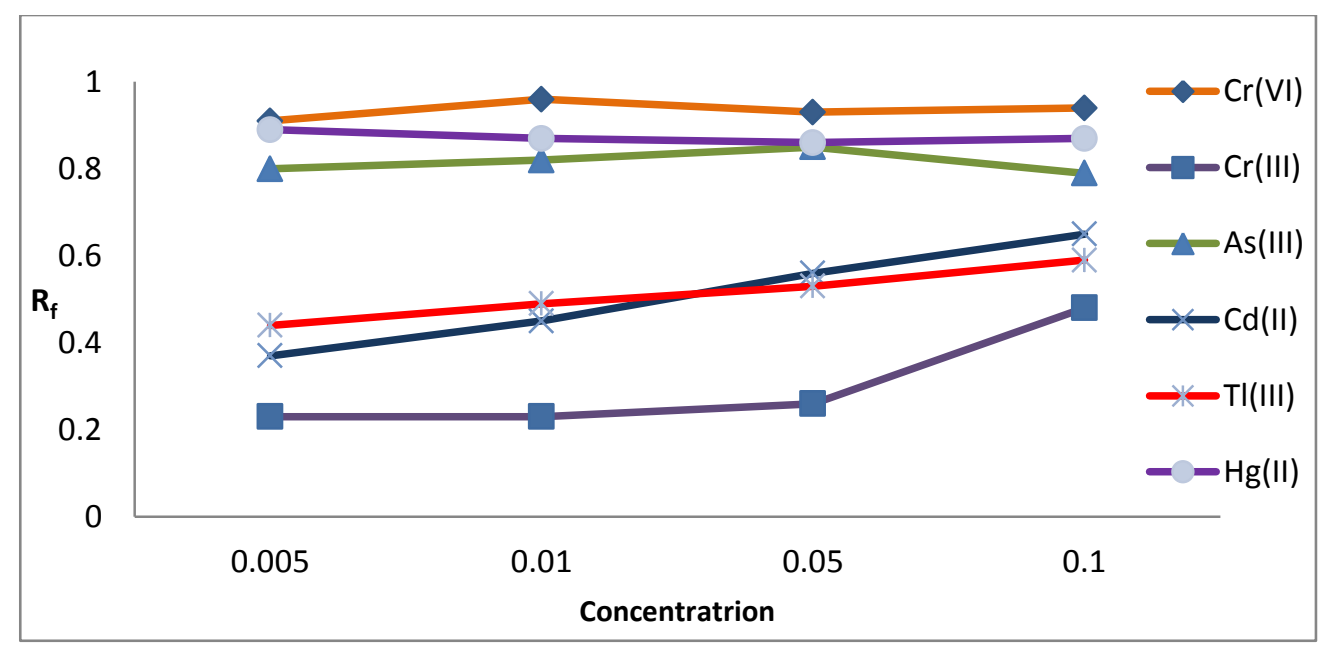

Figure 1. Effect of Concentration.

It was observed that, at concentration $0.1 \mathrm{M}, \mathrm{Cr}(\mathrm{VI})$ was not detected except $\mathrm{pH} 2$, $\mathrm{Cr}(\mathrm{III})$ and $\mathrm{Tl}(\mathrm{III})$ show long tailing while $\mathrm{Hg}$ (II) shows spreading. At $0.05 \mathrm{M}$ concentration of l-Alanine, almost same results were observed. At $0.01 \mathrm{M} 1$-Alanine spots were not compact and shows little spreading, especially $\mathrm{Cr}(\mathrm{VI}) ; \mathrm{Cd}(\mathrm{II}) ; \mathrm{Hg}(\mathrm{II})$. However, at $0.005 \mathrm{M}$ concentration compact spot were observed, hence this concentration was selected as the optimum separating concentration for further studies.

\section{Effect of $p H$}

This section deals with effect of $\mathrm{pH}$ on $\mathrm{R}_{\mathrm{f}}$ values of metal ions. The effect of $\mathrm{pH}$ on the $\mathrm{R}_{\mathrm{f}}$ values of different metal ions was carefully studied by conducting several sets of experiments. The plates were run near about to $10 \mathrm{~cm}$ above from the base line. The results are graphically represented in fig $\mathbf{2}$ and tabulated in table $\mathbf{2}$ which reveal variations in the $R_{f}$ values with $\mathrm{pH}$ of l-Alanine. The measurements of $\mathrm{R}_{\mathrm{f}}$ values were done in the $\mathrm{pH}$ range of 1.0 to 7.0 at $0.005 \mathrm{M}$ concentration.

Table 2. Effect of $\mathrm{pH}$.

Mobile Phase: 1-Alanine, Concentration $-0.005 \mathrm{M}$.

\begin{tabular}{|c|c|c|c|c|c|c|c|c|c|}
\hline \multirow{2}{*}{$\begin{array}{c}\text { Metal } \\
\text { Ions }\end{array}$} & \multicolumn{9}{|c|}{$\mathrm{pH}$ of Mobile Phase } \\
\cline { 2 - 10 } & 1 & 2 & 2.5 & 3 & 3.5 & 4 & 5 & 6 & 7 \\
\hline $\mathrm{Cr}$ (VI) & 0.95 & 0.94 & 0.90 & 0.95 & 0.95 & 0.94 & $0.94 \mathrm{D} . \mathrm{S}$ & $0.95 \mathrm{D} . \mathrm{S}$ & $0.94 \mathrm{D} . \mathrm{S}$ \\
\hline $\mathrm{Cr}$ (III) & 0.70 & 0.58 & 0.34 & 0.23 & 0.22 & 0.28 & $0.26 \mathrm{~T}$ & $0.37 \mathrm{~T}$ & $0.35 \mathrm{~T}$ \\
\hline As (III) & 0.83 & 0.86 & 0.80 & 0.83 & 0.84 & 0.88 & 0.88 & 0.81 & 0.85 \\
\hline $\mathrm{Cd}$ (II) & 0.90 & 0.66 & 0.48 & 0.36 & 0.29 & $0.32 \mathrm{~T}$ & $0.27 \mathrm{~T}$ & $0.27 \mathrm{~T}$ & $0.35 \mathrm{~T}$ \\
\hline $\mathrm{Tl}$ (III) & 0.64 & 0.60 & 0.49 & 0.45 & 0.43 & $0.46 \mathrm{~T}$ & $0.46 \mathrm{~T}$ & $0.46 \mathrm{~T}$ & $0.47 \mathrm{~T}$ \\
\hline $\mathrm{Hg}$ (II) & 0.95 & 0.97 & 0.96 & 0.93 & 0.91 & 0.91 & $0.95 \mathrm{spr}$ & $0.97 \mathrm{spr}$ & $0.97 \mathrm{spr}$ \\
\hline
\end{tabular}

Notation: - T. - Tailing; Spr. - Spreading; D.S. - Double Spot. 


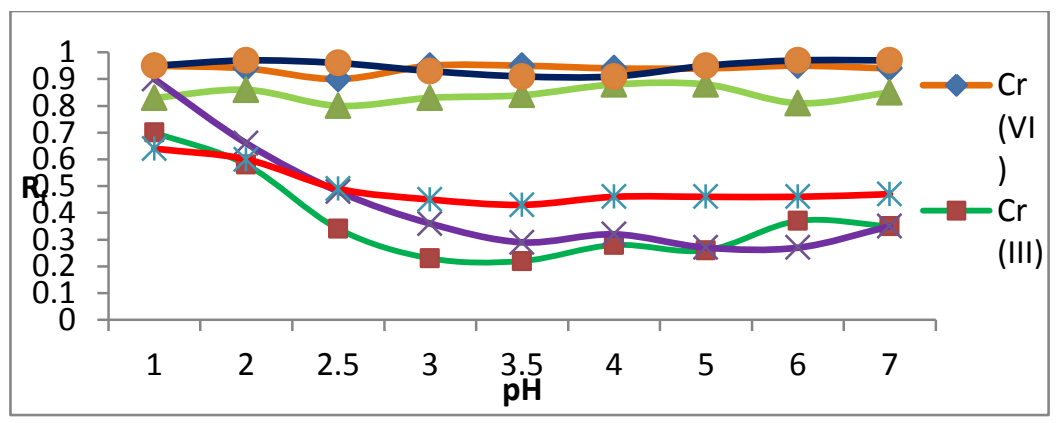

Figure 2. Effect of $\mathrm{pH}$.

Mobile Phase: 1-Alanine, Concentration - 0.005 M.

It was observed from Table No 2 and fig 2 that, at low $\mathrm{pH}$, all the six metal ions move with the solvent. It is noted that all metal ions showed very little difference in the $\mathrm{R}_{\mathrm{f}}$ values at $\mathrm{pH} 2.0$, but as we increase the $\mathrm{pH}$ from 2.5 to $\mathrm{pH}$ 4.0. Maximum difference in the $\mathrm{R}_{\mathrm{f}}$ values of different metal ions were seen at $\mathrm{pH}$ 3.5. This was required for better separation. However, the behavior of cations changed after the increase in $\mathrm{pH} 4.0$ and above, especially at $\mathrm{pH} 5.0, \mathrm{Cr}(\mathrm{VI})$ shows double spotting due to formation of hetero poly acid ; $\mathrm{Cr}(\mathrm{III})$; $\mathrm{Cd}(\mathrm{II})$; \& $\mathrm{Tl}(\mathrm{III})$ show tailing whereas $\mathrm{Hg}(\mathrm{II})$ shows spreading. But As(III) shows compact spot at all $\mathrm{pH}$ except $\mathrm{pH}$ 1. From these observed values, $\mathrm{pH} 3.5$ has been found out to be ideal for bringing out maximum separation. $\mathrm{R}_{\mathrm{f}}$ of all mention metal ions was not possible to measure above $\mathrm{pH}$ 7. Hence, separation measurements have been carried between $\mathrm{pH} 3.5$ and $\mathrm{pH} 7.0$ in aqueous media of $1-$ Alanine.

\section{Conclusion}

Using the above mentioned optimum separating conditions, that is $0.005 \mathrm{M}$ 1-Alanine at $\mathrm{pH}$ 3.5, qualitative separation of eight binary mixtures; seven ternary mixtures; and four quaternary mixtures of metal ions have been carried out. Various binary, ternary and quaternary separations have been listed in Table 3,4 , and 5 respectively. The $\mathrm{R}_{\mathrm{f}}$ values of metal cations are given in top to bottom format, as they appear on the chromatographic plate. Photograph of binary, ternary and quaternary separations have been depicted in picture number 1,2 and 3 respectively.

Experimentally achieved separations on silica gel-G layers developed in aqueous l-Alanine as mobile phase with optimum separating conditions.

Table 3. Binary Separations.

Mobile Phase: 1-Alanine, Concentration $-0.005 \mathrm{M}, \mathrm{pH}-3.5$.

\begin{tabular}{|c|c|c|}
\hline Sr. No & Components & $\mathrm{R}_{\mathrm{f}}$ Values of Metal ions \\
\hline 1 & $\mathrm{Cr}(\mathrm{VI}) ; \mathrm{Cr}$ (III) & $\mathrm{Cr}(\mathrm{VI})$ - 0.97; Cr (III) - 0.38. \\
\hline 2 & $\mathrm{Cr}$ (VI);As (III) & Cr (VI) - 0.97; As (III) - 0.80. \\
\hline 3 & $\mathrm{Cr}(\mathrm{VI}) ; \mathrm{Cd}(\mathrm{II})$ & Cr (VI) - 0.97; Cd (II) - 0.44. \\
\hline 4 & $\mathrm{Cr}$ (VI);Tl (III) & $\mathrm{Cr}(\mathrm{VI})$ - 0.98; Tl (III) - 0.18. \\
\hline 5 & $\mathrm{Hg}(\mathrm{II}) ; \mathrm{Cr}$ (III) & $\mathrm{Hg}(\mathrm{II})-0.71 ; \mathrm{Cr}$ (III) -0.35 \\
\hline 6 & As (III);Cd (II) & As (III) - $0.85 ; \mathrm{Cd}$ (II) - 0.44 . \\
\hline 7 & $\mathrm{Hg}(\mathrm{II}) ; \mathrm{Cd}(\mathrm{II})$ & $\mathrm{Hg}(\mathrm{II})-0.74 ; \mathrm{Cd}$ (II) -0.53 \\
\hline 8 & $\mathrm{Cr}$ (VI:)Hg (II) & $\mathrm{Cr}(\mathrm{VI})-0.97: \mathrm{Hg}(\mathrm{II})-0.76$ \\
\hline
\end{tabular}


Table 4. Ternary Separations.

\begin{tabular}{|c|c|c|}
\hline Sr. No & Components & $\mathrm{R}_{\mathrm{f}}$ Values of Metal ions \\
\hline 1 & $\mathrm{Cr}$ (VI); As (III); Cr (III). & $\mathrm{Cr}$ (III) - 0.96; As (III) - 0.29; Cr (III) - 0.37. \\
\hline 2 & $\mathrm{Cr}$ (VI); Cd (II); Cr (III). & $\mathrm{Cr}(\mathrm{VI})-0.98 ; \mathrm{Cd}(\mathrm{II})-0.59 ; \mathrm{Cr}(\mathrm{III})-0.64$ \\
\hline 3 & Hg (II);Cd (II); Tl (III) & $\mathrm{Hg}(\mathrm{II})-0.85 ; \mathrm{Cd}$ (II) - 0.34; Tl (III) - 0.23. \\
\hline 4 & $\mathrm{Cr}$ (VI); Cd (II); Tl (III). & $\mathrm{Cr}(\mathrm{VI})-0.97 ; \mathrm{Cd}(\mathrm{II})-0.39 ; \mathrm{Tl}(\mathrm{III})-0.25$. \\
\hline 5 & As (III); Hg (II); Cd (II) & As (III) $-0.83 ; \mathrm{Hg}(\mathrm{II})-0.62 ; \mathrm{Cd}$ (II) - 0.36 \\
\hline 6 & Cr (IV); As (III); Cd (III). & Cr (IV) - 0.98; As (III) - 0.80; Cd (III) - 0.50. \\
\hline 7 & As (III); Cd (II); Cr (III). & As (III) - 0.81; Cd (II) - 0.50; Cr (III) - 0.31. \\
\hline
\end{tabular}

Table 5. Quaternary Separations.

\begin{tabular}{|c|c|c|}
\hline Sr. No. & Components & $\mathrm{R}_{\mathrm{f}}$ Values of Metal ions \\
\hline 1. & $\mathrm{Cr}(\mathrm{VI}) ; \mathrm{As}(\mathrm{III}) ;$ & $\mathrm{Cr}(\mathrm{VI})-0.97 ; \mathrm{As}(\mathrm{III})-0.23 ;$ \\
& $\mathrm{Cr}(\mathrm{III}) ; \mathrm{Tl}(\mathrm{III})$. & $\mathrm{Hg}(\mathrm{II})-0.22 ; \mathrm{Tl}$ (III) -0.30. \\
\hline 2. & $\mathrm{Hg}(\mathrm{II}) ; \mathrm{As}(\mathrm{III}) ;$ & $\mathrm{As}(\mathrm{III}) 0.83 ;$ \\
& $\mathrm{Cd}(\mathrm{II}) ; \mathrm{Tl}(\mathrm{III})$. & $\mathrm{Cd}(\mathrm{II})-0.46 ; \mathrm{Tl}(\mathrm{III})-0.32$. \\
\hline 3. & $\mathrm{Cr}(\mathrm{VI}) ; \mathrm{As}(\mathrm{III}) ;$ & $\mathrm{Cr}(\mathrm{VI})-0.96 ; \mathrm{As}(\mathrm{III})-0.81 ;$ \\
& $\mathrm{Cd}(\mathrm{II}) ; \mathrm{Cr}(\mathrm{III})$. & $\mathrm{Cd}(\mathrm{II})-0.45 ; \mathrm{Cr}(\mathrm{III})-0.33$. \\
\hline 4. & $\mathrm{Hg}(\mathrm{II}) ; \mathrm{As}(\mathrm{III}) ;$ & $\mathrm{Hg}(\mathrm{II})-0.70 \mathrm{As}(\mathrm{III})-0.86 ;$ \\
& $\mathrm{Cd}(\mathrm{II}) ; \mathrm{Cr}(\mathrm{III}) ;$ & $\mathrm{Cd}(\mathrm{II})-0.49 ; \mathrm{Cr}(\mathrm{III})-0.23 ;$ \\
\hline
\end{tabular}

There is a slight difference in the $\mathrm{R}_{\mathrm{f}}$ values of metal ions during the separations from their mixtures, due to the mutual interaction of metal ions.

Pictures for the achieved separations using above mentioned optimum separating conditions are shown below.

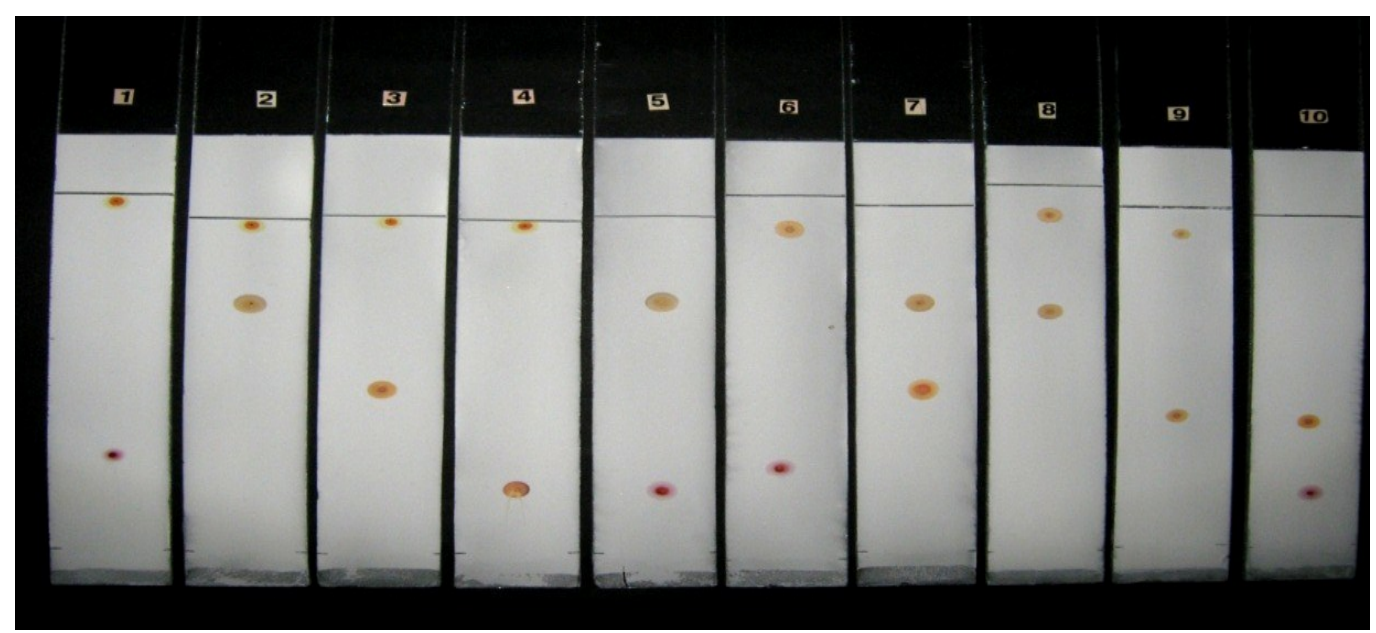

Picture No 1. Binary Separations. 


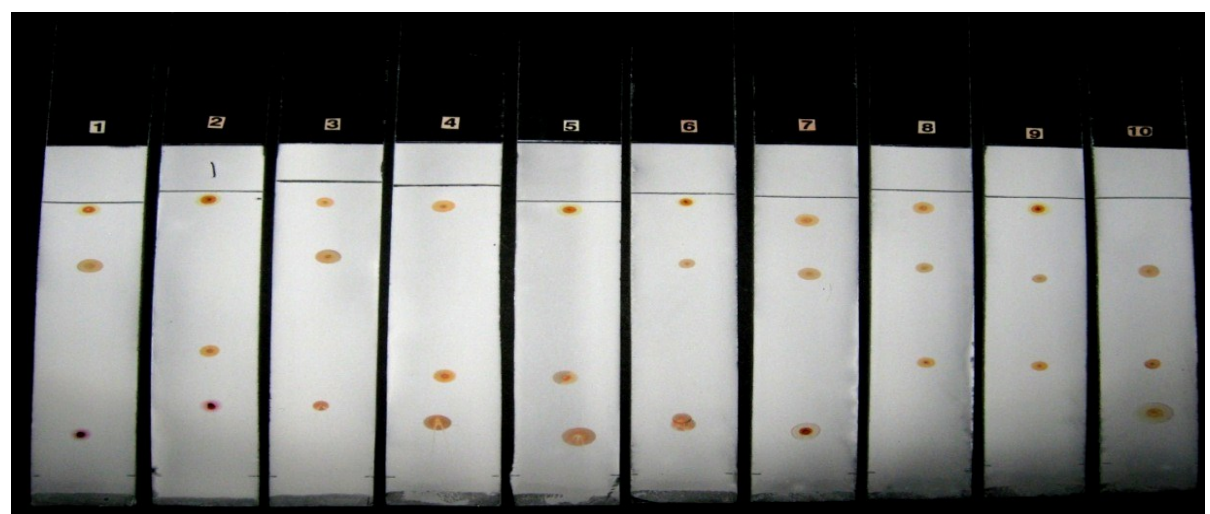

Picture No 2. Ternary Separations.

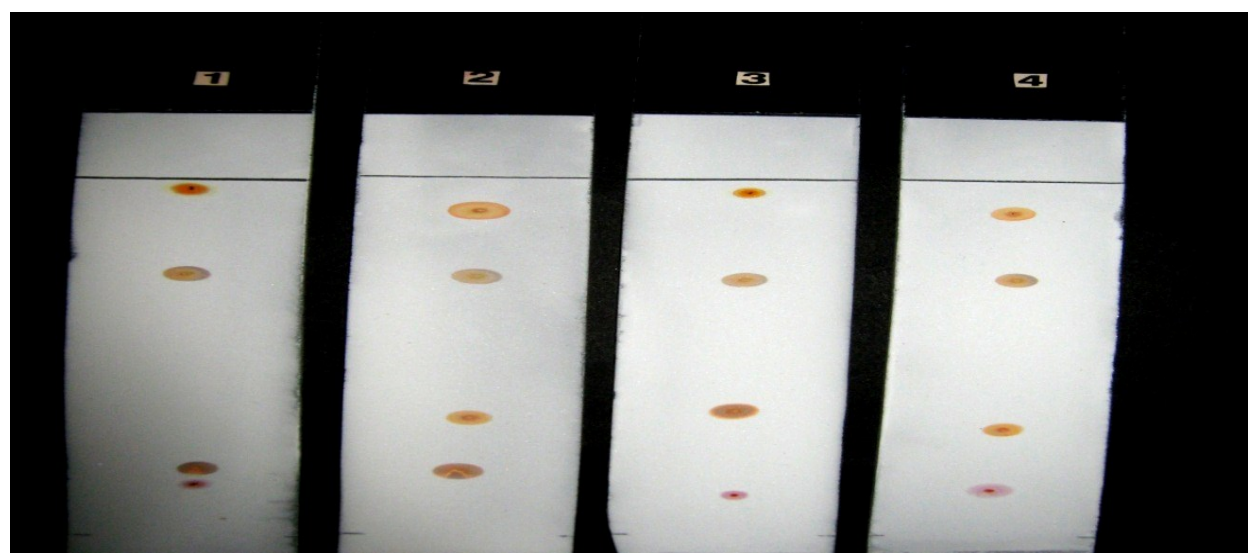

Picture No 3. Quaternary Separations.

\section{Acknowledgement}

The authors are thankful to The Principal, Dr. Dipti Christian, and Dr. R. M. Uttarwar, The Head, Department of Chemistry, Hislop College, Nagpur, (M.S.) India for providing research facilities used in the present study.

\section{References}

1. Deshmukh L., Kharat R. B., Intern J. Environ. Anal Chem 1988; Vol.36, 1-6.

2. Deshmukh L., Kharat R.B., Journal of Liquid Chromatography 1989, 12(6), 937-947.

3. Thielemann H, Acta Hydrochem. Hydrobio. (1977), 5, 191-193.

4. Armstrong D W; Terrill R Q, Anal. Chem. 1979, 51, 2160-2163.

5. Borgerding M F, Williams (Jr), R L, Hinze W L, Quina J. Liq. Chromatography,12, (1989), 1367-1406.

6. Kord A S, Khaledi M G, Anal Chem. 1992, 64, 1901-1907. 
7. Szymanski A, Szczepaniak W Chem. Anal. Warsaw, 1998, 43, 346-349.

8. Khaledi M G, Strasters J K, Rodgers A H, Breyer E D, Anal. Chem. 1990, 62, 130-136.

9. Mohammad A, Agrawal V J, Planar Chromatography, Mod.-TLC, 2000, 13, 210-216.

10. Mohammad A, Sirwal Y H, J. Planar Chromatography-Mod.TLC, 2001, 15, 107-115.

11. Dingmi S, Suya L, Taohui L, Fenxi Huaxue, 1984, 12, 934; C.A. 1985, 102, 7195 V.

12. Mohammad A. Eram Iraqi and Iftkhar Alam Khan. J. of Surfactant and Detergent, 1999, Vol. 2; No.4, 523-529.

13. Mohammad A, Agrawal V, Nahed Jabeen. Chromatography, 2003, 24, 2 1-7.

14. Yeole C G, Shinde V M, Analyst. 1983, 104, 1102-1107.

15. Dorsey J G, De Etchegaray M T, Landy J S, anal. Cham. 1983, 55, 924-928.

16. Perisic-Janjic N U, Petrovic S M, Djakovic T L, presented at Budapest Chromatography conference, 24-17 August(1990), Budapest.

17. Feigl F, 'Spot Test Inorganic Applications' Elsevier Pub. Co., Amsterdam $4^{\text {th }}$ Ed. 1954.

18. Piefer J J, Microchim Acta, 1962, 529. 


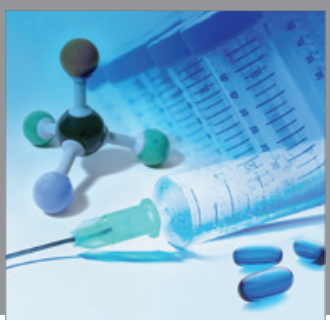

International Journal of

Medicinal Chemistry

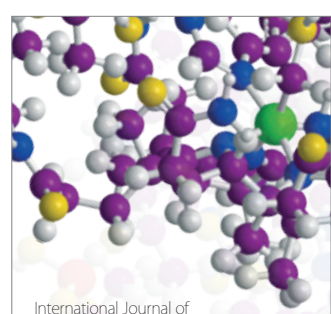

Carbohydrate Chemistry

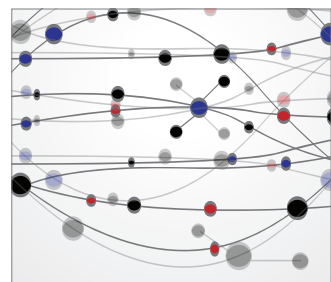

The Scientific World Journal
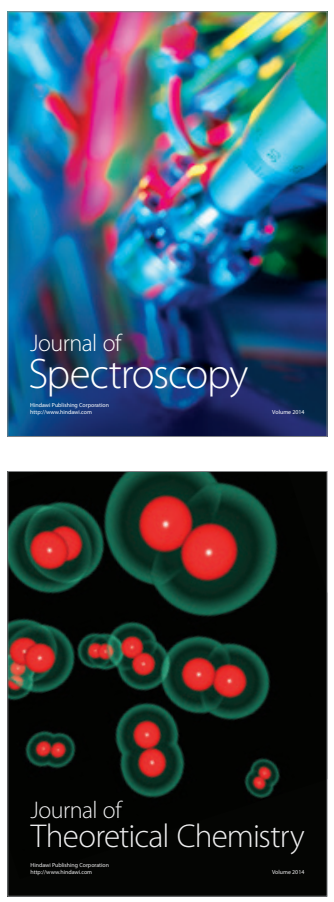
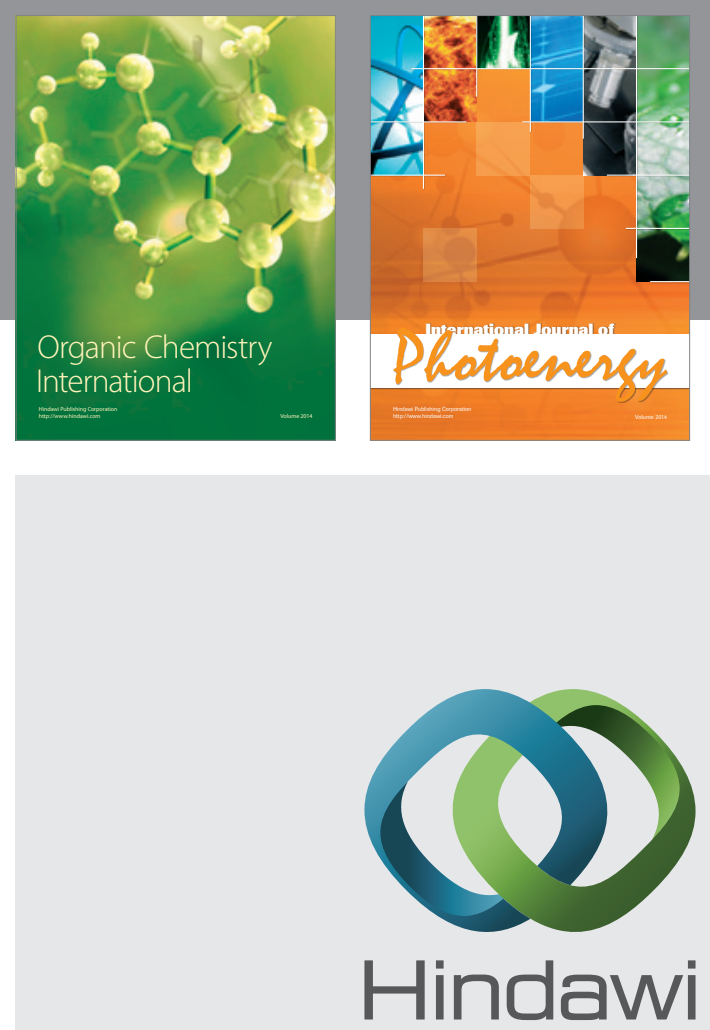

Submit your manuscripts at

http://www.hindawi.com
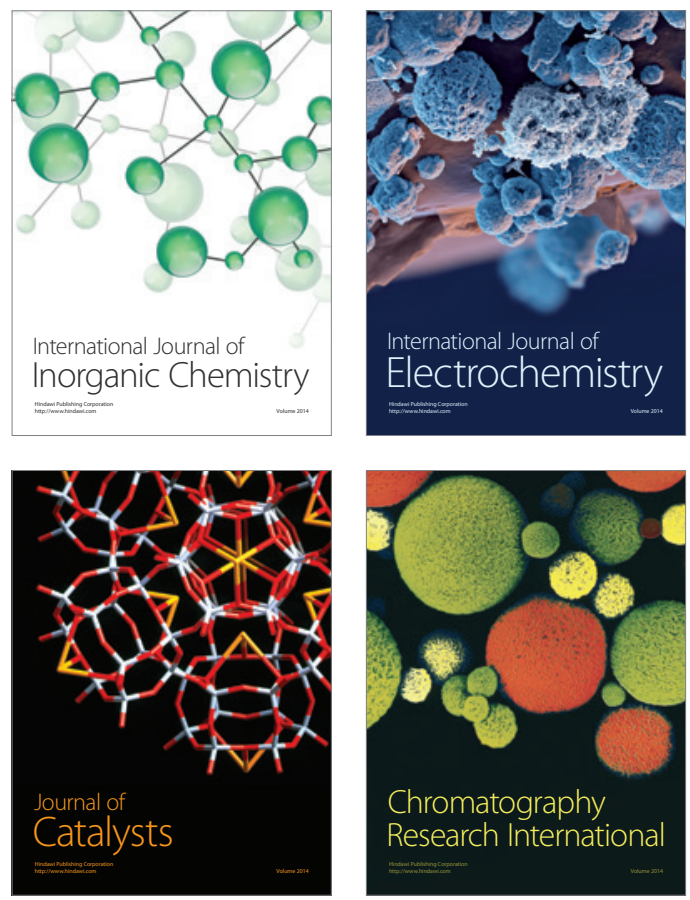
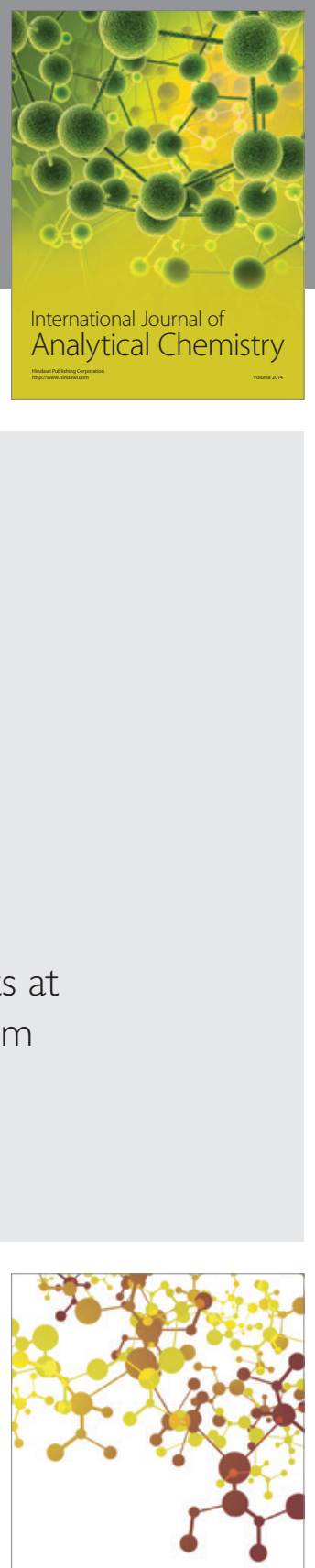

Journal of

Applied Chemistry
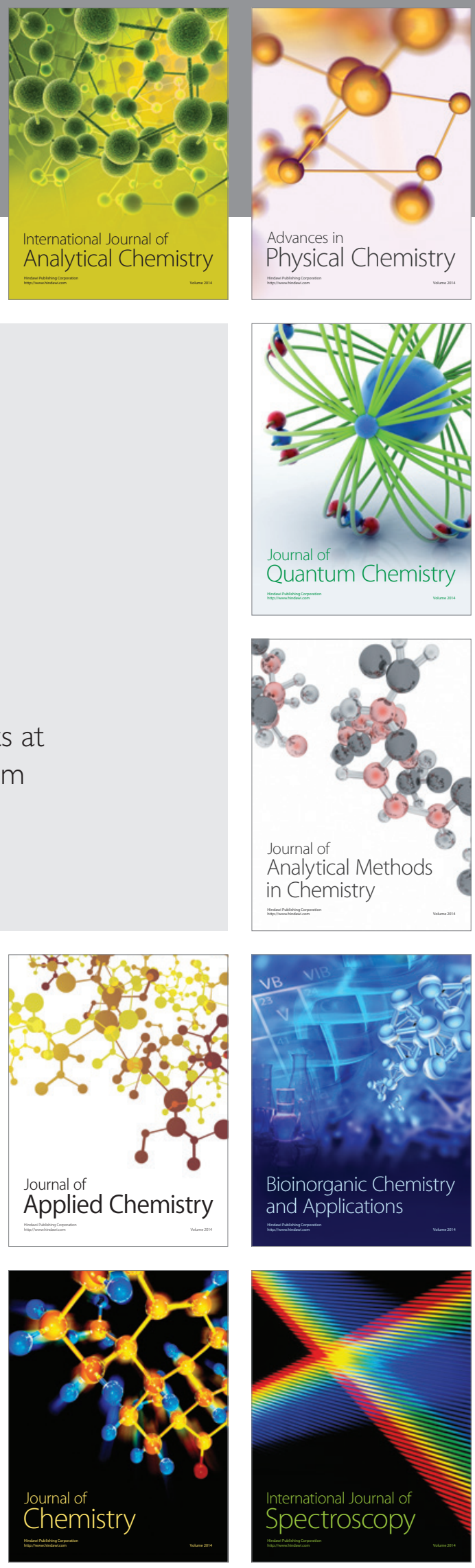